\title{
Growth-inhibitory effects of the chemopreventive agent indole-3- carbinol are increased in combination with the polyamine putrescine in the SW480 colon tumour cell line
}

\author{
E Ann Hudson*1, Lynne M Howells1, Barbara Gallacher-Horley², \\ Louise $\mathrm{H} \mathrm{Fox}^{1}$, Andreas Gescher ${ }^{3}$ and Margaret M Manson ${ }^{1}$
}

\author{
Address: ${ }^{1}$ Cancer Biomarkers and Prevention Group, Departments of Biochemistry \& Oncology, University of Leicester, Leicester, LE1 7RH, UK, \\ ${ }^{2}$ MRC Toxicology Unit, Leicester, LE1 9HN, UK and ${ }^{3}$ Cancer Biomarkers and Prevention Group, Department of Oncology, University of Leicester, \\ Leicester, LE2 7LX, UK \\ Email: E Ann Hudson* - eah5@le.ac.uk; Lynne M Howells - lh28@le.ac.uk; Barbara Gallacher-Horley - bg10@le.ac.uk; \\ Louise H Fox - lhf2@le.ac.uk; Andreas Gescher - ag15@le.ac.uk; Margaret M Manson -mmm2@le.ac.uk \\ * Corresponding author
}

Published: 14 January 2003

BMC Cancer 2003, 3:2

This article is available from: http://www.biomedcentral.com/I47I-2407/3/2
Received: 8 July 2002

Accepted: 14 January 2003

(C) 2003 Hudson et al; licensee BioMed Central Ltd. This is an Open Access article: verbatim copying and redistribution of this article are permitted in all media for any purpose, provided this notice is preserved along with the article's original URL.

\begin{abstract}
Background: Many tumours undergo disregulation of polyamine homeostasis and upregulation of ornithine decarboxylase (ODC) activity, which can promote carcinogenesis. In animal models of colon carcinogenesis, inhibition of ODC activity by difluoromethylornithine (DFMO) has been shown to reduce the number and size of colon adenomas and carcinomas. Indole-3-carbinol (I3C) has shown promising chemopreventive activity against a range of human tumour cell types, but little is known about the effect of this agent on colon cell lines. Here, we investigated whether inhibition of ODC by I3C could contribute to a chemopreventive effect in colon cell lines.
\end{abstract}

Methods: Cell cycle progression and induction of apoptosis were assessed by flow cytometry. Ornithine decarboxylase activity was determined by liberation of $\mathrm{CO}_{2}$ from ${ }^{14} \mathrm{C}$-labelled substrate, and polyamine levels were measured by HPLC.

Results: I3C inhibited proliferation of the human colon tumour cell lines HT29 and SW480, and of the normal tissue-derived HCEC line, and at higher concentrations induced apoptosis in SW480 cells. The agent also caused a decrease in ODC activity in a dose-dependent manner. While administration of exogenous putrescine reversed the growth-inhibitory effect of DFMO, it did not reverse the growth-inhibition following an I3C treatment, and in the case of the SW480 cell line, the effect was actually enhanced. In this cell line, combination treatment caused a slight increase in the proportion of cells in the $\mathrm{G}_{2} / \mathrm{M}$ phase of the cell cycle, and increased the proportion of cells undergoing necrosis, but did not predispose cells to apoptosis. Indole-3-carbinol also caused an increase in intracellular spermine levels, which was not modulated by putrescine co-administration.

Conclusion: While indole-3-carbinol decreased ornithine decarboxylase activity in the colon cell lines, it appears unlikely that this constitutes a major mechanism by which the agent exerts its antiproliferative effect, although accumulation of spermine may cause cytotoxicity and contribute to cell death. The precise mechanism by which putrescine enhances the growth inhibitory effect of the agent remains to be elucidated, but does result in cells undergoing necrosis, possibly following accumulation in the $G_{2} / M$ phase of the cell cycle. 


\section{Background}

There is strong epidemiological evidence to support a protective role of fruit and vegetables against the development of cancer in a range of major organs, in particular of the breast and the digestive tract. This evidence has led to the isolation and characterisation of discreet dietary constituents that may be responsible for their chemopreventive activity. I3C is derived from cruciferous vegetables such as broccoli and Brussels sprouts, and possesses anticarcinogenic activity in a number of models, both in vivo and in vitro. It has received considerable attention as a potential anti-tumour agent for breast cancer, particularly due to its ability to alter the estrogen metabolite ratio of 2-hydroxyestrone to 16- $\alpha$-hydroxyestrone [1-3], and has recently been the subject of a breast cancer prevention dose-finding pilot study using the urinary estrogen metabolite ratio as the surrogate endpoint biomarker [4]. Promising results have been obtained in phase I clinical trials of I3C against recurrent respiratory papillomatosis or cervical intraepithelial neoplasia $[5,6]$.

I3C has also been shown to protect against carcinogen-induced tumours in a range of rodent models including liver, tongue, skin, mammary tissue and colon [7-12]. Some studies however, have suggested that when administered after chemically-induced initiation, I3C may have promoting activity in liver, raising concerns as to its suitability for use as a chemopreventive agent in humans [1215]. The latter two of these studies showed that in medium and long-term treatment protocols (10 and 30 weeks respectively), I3C increased glutathione $S$-transferase-P (GST-P) positive foci in livers of rats initiated with diethylnitrosamine [15], or in a multi-organ rat model initiated with 7,12-Dimethylbenz [a]anthracene plus azoxymethane plus $\mathrm{AFB}_{1}[12]$, and these results were interpreted as indicating a promoting effect of I3C on hepatocarcinogenesis. In a long-term (48 week) feeding study we showed that $\mathrm{I} 3 \mathrm{C}$ prevented aflatoxin $\mathrm{B}_{1}\left(\mathrm{AFB}_{1}\right)$-induced liver carcinogenesis in Fisher F344 rats, irrespective of whether it was administered before or after the carcinogen [7]. Interestingly, at an earlier time point in our feeding study (13 weeks) we observed strong focal liver staining for $\gamma$-glutamyl transpeptidase and GST-P in rats treated with I3C post-initiation. Using these criteria alone as predictors of tumourigenesis, we would have expected no effect, or indeed an increase in tumours in the livers of these animals. However this was not the case, and at 48 weeks the animals treated with $\mathrm{I} 3 \mathrm{C}$ following $\mathrm{AFB}_{1}$ were completely protected [7]. While the mechanism by which I3C exerts tumour blocking activity has been attributed to the induction of drug metabolising enzymes, which can lead to increased conjugation and excretion of the carcinogen and decreased DNA adduct formation [16-23], the mechanisms by which it suppresses tumour promotion and progression are not well defined.
Inhibition of ornithine decarboxylase (ODC) activity has been proposed as a target mechanism for tumour suppression, reviewed by Pegg [24]. ODC is the rate-limiting enzyme in the biosynthesis of polyamines, which are required for normal cell proliferation. Polyamine levels and ODC activity are elevated in a wide range of tumours, and high levels correlate with poor prognosis in breast cancer patients [25-27]. ODC has further been implicated in the carcinogenic process by findings that overexpression promotes tumourigenesis in vivo, and can be sufficient for transformation of cell lines in vitro [28-31]. Therefore inhibition of ODC activity has been commonly used as a predictor of chemopreventive activity, and as an intermediate endpoint biomarker of clinical efficacy in intervention studies. The regulation of ODC activity within the cell is complex, and occurs at a multitude of levels, [32-34], including protein degradation, post-translational modification, mRNA translation and gene transcription. ODC protein levels are regulated by antizyme, which binds to, and targets ODC for degradation by the 265 proteasome, reviewed in [35]. ODC is also heavily regulated at the level of mRNA translation due to secondary structure in the 5' untranslated region, which can be modified by activity of the translation initiation factor eIF-4E $[32,36]$. The ODC promoter has been shown in various species to be regulated by a number of transcription factors, including the Wilms' tumour suppressor WT1 [3740] and references therein. ODC activity can also be modulated in response to many signalling pathways including the epidermal growth factor receptor, phospho-inositide 3-kinase (PI3K), and estrogen receptor pathways [41-44].

In the long term feeding study mentioned above [7], the level of ODC activity in livers of rats which received dietary I3C was markedly decreased compared to that in rats on a control diet. The current study was designed to explore whether alteration of ODC activity and polyamine levels might play a mechanistic role in the chemopreventive efficacy of I3C in colon cells. To that end the effects of I3C on cell growth, ODC activity and intracellular polyamine levels were studied in human-derived colon cancer cells.

Difluoromethylornithine (DFMO) is a well-studied specific inhibitor of ODC enzyme activity. Initial trials of DFMO as a cancer therapeutic agent were disappointing, showing dose-limiting toxicity, together with little therapeutic activity. The contents of the intestinal and colonic lumen form a rich supply of polyamines, augmented by dietary sources and intestinal bacteria [45-49]. Exogenous polyamines are rapidly taken up by polyamine-depleted cells, and can be utilised for tumour growth [50], offering one explanation for the apparent lack of activity of DFMO in humans. However, more recently, DFMO has 
attracted much interest as a potential chemopreventive agent at lower doses [51-58].

In order to determine any similarity in mechanism of chemopreventive activity between I3C and DFMO the modulation of the growth inhibitory effects of the two agents by polyamines was investigated.

\section{Methods \\ Cell lines and treatments}

Immortalized human colon epithelial cells (HCEC) and human-derived colon carcinoma cell lines SW480 and HT29 were kindly provided by A. Pfeifer (Nestec Ltd., Lausanne, Switzerland) and C. Paraskeva (Bristol University, UK), respectively, and were cultured as described previously $[59,60]$. All cell lines tested negative for mycoplasma infection and were cultured without antibiotics. I3C (Sigma-Aldrich Company Ltd.; Poole, UK) was prepared as a stock solution in DMSO, and cells were treated in such a way that all control and treated cells received equal volumes of DMSO, which did not exceed a final concentration of $0.05 \%$. For each experiment, cells were seeded in normal growth medium and were allowed to adhere for at least 4 hours before treatment. Cells were treated with concentrations of I3C from $100 \mu \mathrm{M}$ up to 1 $\mathrm{mM}$ in some experiments. It should be noted that any effects seen at concentrations above $500 \mu \mathrm{M}$ are unlikely to be physiologically relevant. All cell culture reagents (GIB$\mathrm{CO}$ ) were purchased from Invitrogen Ltd. (Paisley, UK).

\section{Cell growth assays}

Cells were seeded at $1 \times 10^{4}$ onto 24 well plates in normal growth medium, and allowed to adhere, prior to treatment with I3C for times up to 10 days. The culture medium was not changed during the incubation time. Cells were harvested by trypsinisation at 24 hourly intervals and counted on a Coulter ZM electronic cell counter (Beckman Coulter UK Ltd., High Wycombe, UK).

Mean $\mathrm{IC}_{50}$ values were obtained from plots of cell number expressed as a percentage of control, versus I3C concentration following treatment for 7 days. In further growth experiments, HT29 and SW480 cells were treated with concentrations of I3C (250 or $175 \mu \mathrm{M}$ respectively), or DFMO (125 or $50 \mu \mathrm{M}$; CN Biosciences (UK) Ltd., Beeston, $\mathrm{UK}$ ), and cultured for 7 days in the presence or absence of putrescine as indicated. To determine their ability to recover proliferative capacity following treatment, cells $(1 \times$ $10^{4}$ on 12 well plates) were cultured in the presence of I3C, plus or minus putrescine, for 24 hours, after which they were either maintained in treated medium or washed and replenished with fresh medium and allowed to recover before harvesting on day 7 . The proliferation rate of cells was calculated as fold increase in cell number following the initial treatment period.
For analysis of cell cycle, $5 \times 10^{5}$ cells were seeded onto 9 $\mathrm{cm}$ plates and treated with $\mathrm{I} 3 \mathrm{C}$ in the presence or absence of putrescine for 96 hours. Cells were harvested by trypsinisation and fixed overnight in $70 \%$ ethanol at $4{ }^{\circ} \mathrm{C}$, then collected by centrifugation and resuspended in PBS containing $0.1 \mathrm{mg} / \mathrm{ml} \mathrm{RNase}$ and $5 \mu \mathrm{g} / \mathrm{ml}$ propidium iodide and incubated overnight at $4{ }^{\circ} \mathrm{C}$. DNA content was analysed using a Becton Dickinson FACScan and Cell Quest software, plotting 5000 events per sample. Subsequent data analysis was performed using ModFit LT software (Becton Dickinson UK Ltd.; Cowley, UK).

\section{Measurement of phosphatidylserine externalisation}

Cells were seeded at $2-5 \times 10^{5}$ onto $9 \mathrm{~cm}$ plates and treated with I3C for 96 hours. After treatment, cells obtained by trypsinisation were combined with those that had spontaneously detached during the incubation. Phosphatidylserine externalisation was determined by annexin $\mathrm{V}$ staining. Cells were pelleted and resuspended in $1 \mathrm{ml}$ annexin buffer (10 mM HEPES pH 7.4, $150 \mathrm{mM} \mathrm{NaCl}, 5$ $\left.\mathrm{mM} \mathrm{KCl}, 1 \mathrm{mM} \mathrm{MgCl}_{2}, 1.8 \mathrm{mM} \mathrm{CaCl}_{2}\right)$. FITC-conjugated annexin $\mathrm{V}$ was added to a final concentration of $100 \mathrm{ng} /$ $\mathrm{ml}$ and cells were incubated for $8 \mathrm{~min}$ at room temperature, after which propidium iodide $(1.5 \mu \mathrm{g})$ was added and cells were analysed by flow cytometry using a FACScan flow cytometer (Becton Dickinson, San Jose, CA) and Cell Quest software.

\section{Measurement of ODC activity}

Colon cells were seeded at $5 \times 10^{5}$ onto $9 \mathrm{~cm}$ plates and allowed to adhere prior to treatment with I3C for 24 hours. Whole cell lysates were prepared by successive rounds of freeze thawing of cells suspended in $200 \mu \mathrm{l}$ sodium phosphate buffer (100 mM, pH 7.2). ODC activity in cell lysates $(90 \mu \mathrm{l})$ was determined by measurement of ${ }^{14} \mathrm{CO}_{2}$ released from labelled ornithine, under reaction conditions described previously [7]. Protein content of cell lysates was determined using the BioRad protein assay kit (Bio-Rad Laboratories Ltd., Hemel Hempstead, UK). ODC activity was calculated as pmol $\mathrm{CO}_{2}$ produced/ $\mathrm{mg}$ protein/ hour, and results are expressed as a percentage of activity in control samples (DMSO-treated).

\section{Measurement of intracellular polyamine levels}

Cells seeded onto $9 \mathrm{~cm}$ plates at densities between $5 \times 10^{5}$ and $2 \times 10^{6}$ depending on treatment time, were treated with I3C in the presence or absence of putrescine for 24, 96 or 168 hours, and were then harvested and washed twice with PBS. Cell pellets were resuspended in $200 \mu \mathrm{l}$ $10 \%$ trichloroacetic acid, and the acid-soluble polyamines extracted by centrifugation. Dansylated polyamines were detected by fluorescence, following separation by ionpairing reversed phase HPLC. Dansylation and extraction of polyamines was based on published methods $[61,62]$. In brief, extracts were mixed with $400 \mu$ ldansyl chloride 
SW480

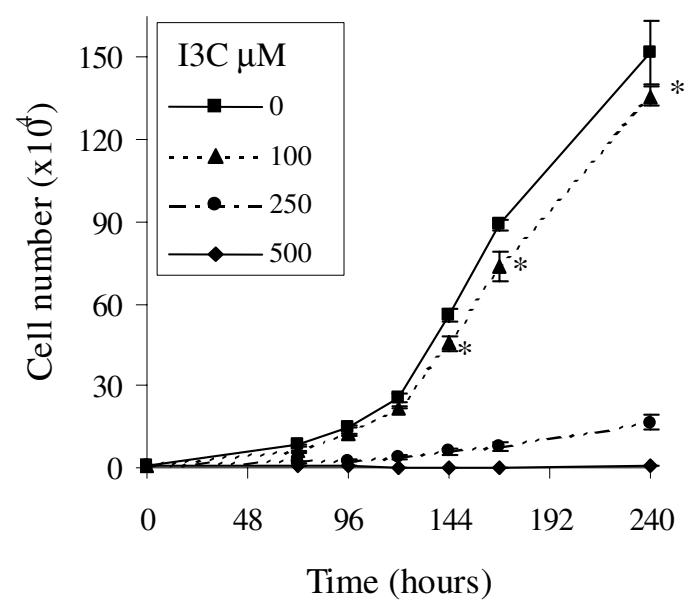

HT29

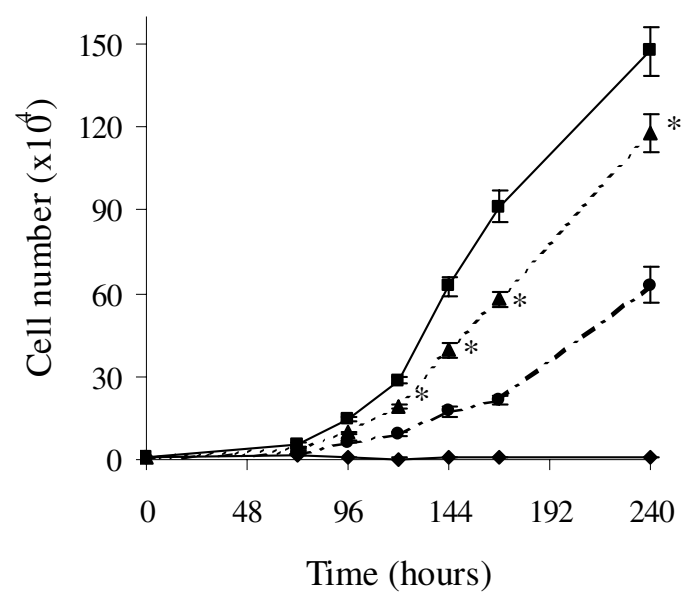

\section{HCEC}

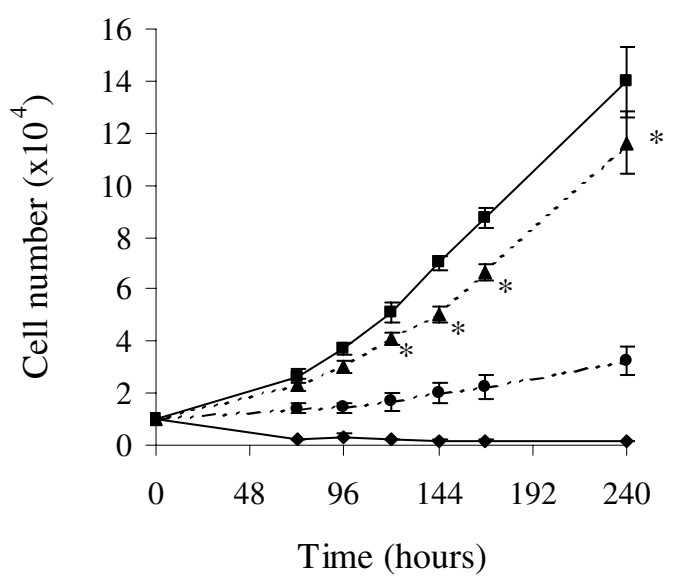

\section{Figure I}

Inhibition of cell growth by I3C. Cells were treated with I3C and counted at 24 hourly intervals as described in Materials and Methods. Results are presented as mean $\pm \operatorname{SEM}(n=6), *$ indicates significant difference from control cell numbers at that time point $(P<0.05)$. 
( $5 \mathrm{mg} / \mathrm{ml}$ in acetone) in the presence of approximately $300 \mathrm{mg}$ solid sodium carbonate, together with $500 \mathrm{nmol}$ of the internal standard 1,6-hexanediamine, and incubated for $20 \mathrm{~min}$ at $70^{\circ} \mathrm{C}$. Reactions were allowed to cool to room temperature and excess dansyl chloride was sequestered by the addition of $200 \mu \mathrm{l}$ proline $(250 \mathrm{mg} / \mathrm{ml})$. Polyamines were then extracted into $4 \mathrm{ml}$ cyclohexane, and following evaporation of the cyclohexane were reconstituted in $200 \mu \mathrm{l}$ acetonitrile. Dansylated polyamines were separated and detected using a Gilson 715 series HPLC system with a BDS C18 column $(250 \times 4.6 \mathrm{~mm}$, particle size $3 \mu \mathrm{m}$, Hypersil, Runcorn, UK) coupled to a Waters 470 scanning fluorescence detector (excitation 336 $\mathrm{nm}$, emission $520 \mathrm{~nm}$ ). The mobile phase consisted of a gradient between buffer A $(0.02 \mathrm{M}$ 1-heptanesulphonic acid ( $\mathrm{pH} 3.4)$, acetonitrile, methanol (5:3:2 v/v)) and buffer B (acetonitrile, methanol (3:2 v/v)) essentially as described by Aboul-Enein and Al-Duraibi [63].

\section{Measurement of putrescine uptake}

SW480 cells were seeded at $5 \times 10^{4}$ onto 24 well plates, and treated with I3C $(0-500 \mu \mathrm{M})$ or DFMO $(50 \mu \mathrm{M})$ in 1 $\mathrm{ml}$ medium for 24 hours. Cells were then treated with 10 $\mu \mathrm{l} 10 \mathrm{mM}$ putrescine containing $0.25 \mu \mathrm{Ci}{ }^{14} \mathrm{C}$-labelled putrescine, and incubated for a further $30 \mathrm{~min}$ prior to termination of the experiment. Cells were then washed thoroughly with $1 \mathrm{mM}$ putrescine, and lysed in $250 \mu \mathrm{l} 1$ $\mathrm{M} \mathrm{NaOH} 60^{\circ} \mathrm{C}$ for 1 hour. The lysate was neutralised with $250 \mu \mathrm{l} 1 \mathrm{M} \mathrm{HCl}$, and ${ }^{14} \mathrm{C}$-labelled putrescine that had been incorporated into the cells was determined by scintillation counting. Protein content of the lysates was determined using the BioRad protein assay reagent.

\section{Measurement of intracellular glutathione}

Cells were seeded at $5 \times 10^{4}$ to $1 \times 10^{6}$ onto 6 well plates (according to treatment time) and treated with I3C in the presence or absence of putrescine for 24, 96 or 168 hours. Cells were harvested by trypsinisation and intracellular glutathione levels were determined according to the method of Baker et al. [64].

\section{Statistical analysis}

Data were analysed by ANOVA using either Oneway analysis followed by Tukey's posthoc test, or the General Linear Model twoway analysis followed by Fisher's Least Significant Difference test, as appropriate $[65,66]$.

\section{Results \\ Effect of I3C on proliferation and ODC activity of colon cell lines}

I3C inhibited proliferation of the two tumour-derived colon cell lines SW480 and HT29, and of the normal-derived HCEC cell line (Fig 1). The $\mathrm{IC}_{50} \mathrm{~s}$ (mean $\pm \mathrm{SD}, \mathrm{n}=3$; $168 \mathrm{hr}$ ) for the SW480, HT29 and HCEC cell lines were calculated as $123.22 \pm 8.87 ; 127.20 \pm 8.13$ and $164.5 \pm 7.0$ $\mu \mathrm{M}$ respectively. These values are consistent with concentrations reported to exert biological activity in a range of other cell lines [67-70]. The basal level of ODC activity was low in the normal-derived HCEC line, $156.1 \pm 9.3$ pmol $\mathrm{CO}_{2}$ produced/ hour/ mg protein, while levels were found to vary markedly between the two tumour cell lines. The HT29 line showed high activity, $1079.0 \pm 42.4$, while the SW480 line exhibited activity of $171.3 \pm 20.9$ pmol $\mathrm{CO}_{2}$ produced/ hour/ mg protein. The SW480 cell line is unusual in this respect, as tumour derived cell lines commonly exhibit high levels of ODC activity. I3C decreased basal ODC activity in a dose-dependent manner in all three colon cell lines after treatment for 24 hours (Fig 2), with the HCEC line showing greatest sensitivity, and the SW480 line showing least inhibition. I3C did not inhibit ODC activity when the agent was added directly into an assay (data not shown), indicating that the agent does not act as a direct enzyme inhibitor. Interestingly, the HCEC cell line showed the least decrease in cell number in response to I3C at this time point. This lack of apparent cytotoxicity is in agreement with a recent study by Bonnesen et al. [71], which reported an $\mathrm{IC}_{50}$ in excess of 500 $\mu \mathrm{M}$ I3C in this cell line using MTT tests carried out after 24 hours.

\section{Effect of exogenous putrescine on growth modulation by DFMO and I3C}

To determine the extent to which inhibition of ODC activity contributed to the antiproliferative activity of $\mathrm{I} 3 \mathrm{C}$ in the tumour lines, we made a comparison of its growth inhibitory effect with that of the specific ODC inhibitor, and known antitumour agent, DFMO. The growth inhibitory action of DFMO can be reversed by exogenously added putrescine, which restores intracellular levels of polyamines required for cell proliferation. In all three cell lines, supplementation of culture medium with putrescine reversed the effects of DFMO as expected, and in agreement with data obtained for the HT29 cell line by Gamet et al. [72]. We hypothesised therefore that if the growth-inhibitory effect of I3C was directly related to its ability to decrease ODC activity, then as for DFMO, this may be reversed by supplementation with putrescine. Interestingly, putrescine did not reverse the inhibitory effect caused by I3C in any of the colon cell lines, and at concentrations that did not affect control cell growth (5-100 $\mu \mathrm{M})$, it actually increased growth inhibition of I3C-treated SW480 cells in a dose-dependent manner (Fig. 3; p < $0.05)$. This cell line was also found to be particularly sensitive to exogenously added putrescine, with concentrations in excess of $100 \mu \mathrm{M}$ inhibiting proliferation of control cells. In contrast, the HT29 and HCEC cell lines were resistant to concentrations of exogenous putrescine up to $500 \mu \mathrm{M}$, whether cultured with or without I3C. 

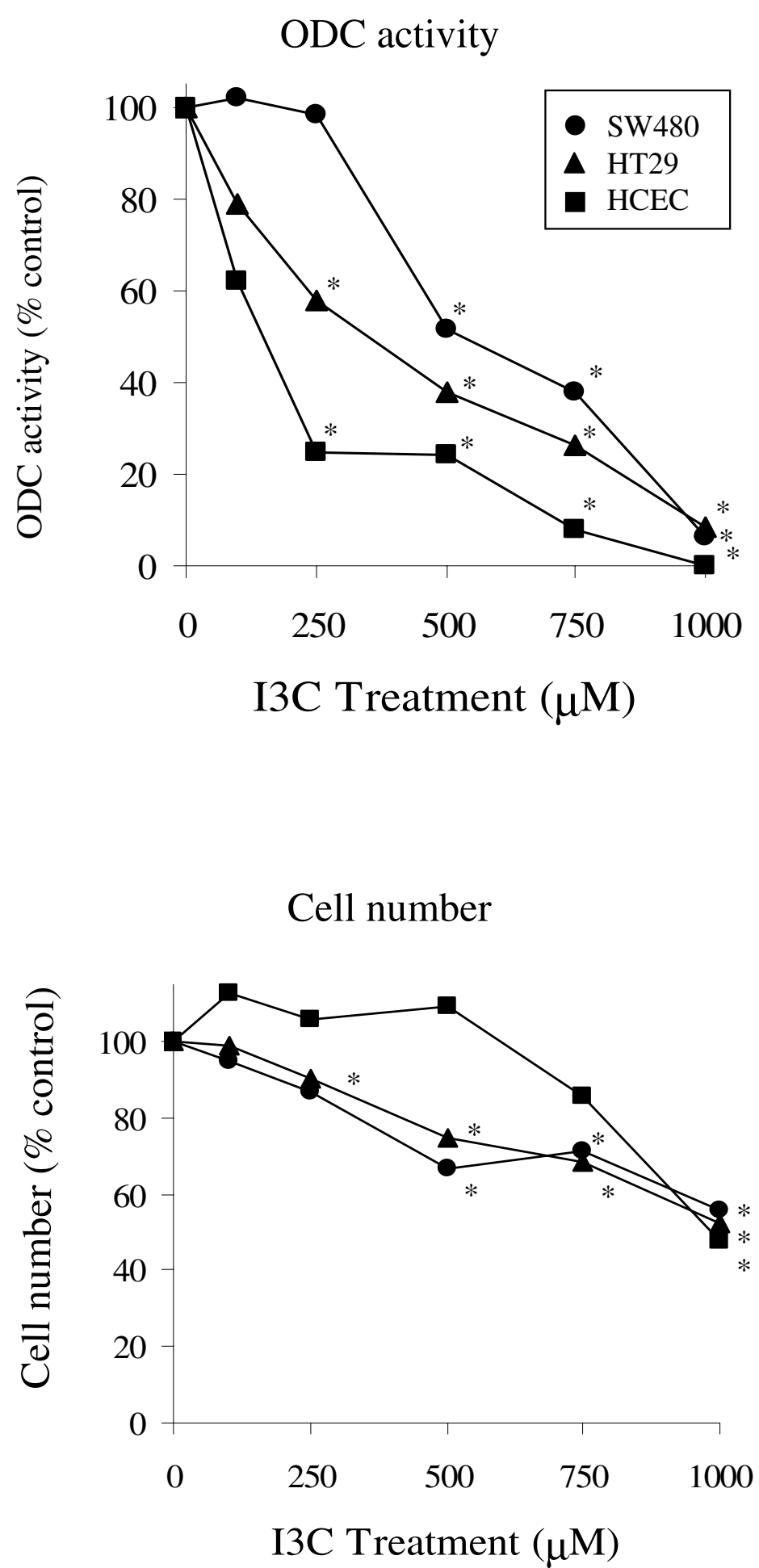

Figure 2

Effect of I3C on basal ODC activity and cell number after 24 hours. ODC activity in cell lysates was determined as described in Materials and Methods. Results are expressed as a percentage of control values $(n=$ minimum of 5; pooled SD of each set for ODC activity and cell number for each cell line are: SW480, I8.76, II.38; HT29, 13.12, 4. I I; HCEC, I5.22, I2.37 respectively). Significant difference from the control (DMSO treated) is indicated by $*(P<0.05)$. 

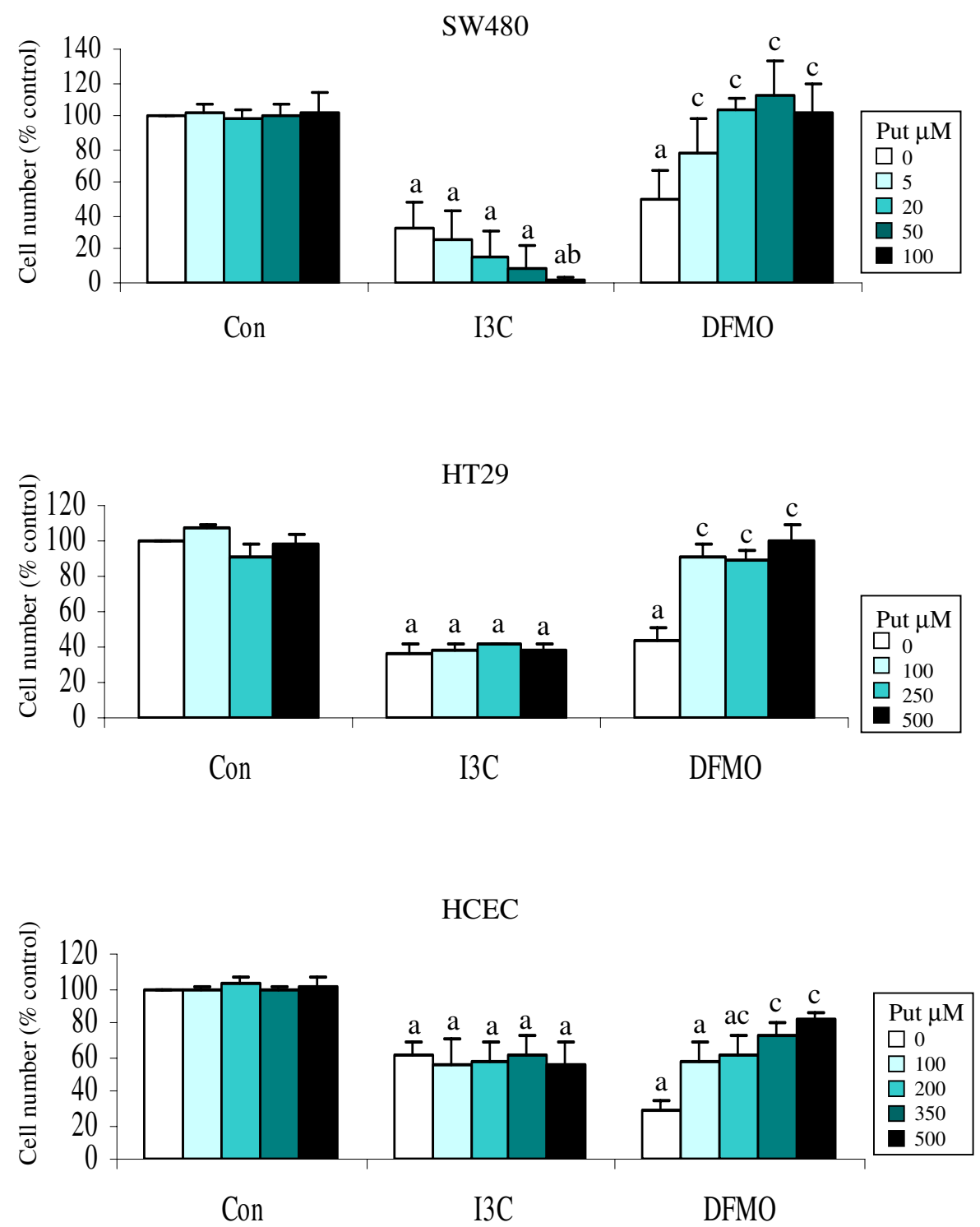

Figure 3

Effect of putrescine supplementation on cell growth inhibition by I3C and DFMO. Cells were treated with I3C (SW480 I75 $\mu$ M; HT29 $250 \mu \mathrm{M}$; HCEC $180 \mu \mathrm{M}$ ) or DFMO (SW480 $50 \mu \mathrm{M}$; HT29 and HCEC $125 \mu \mathrm{M}$ ) or DMSO (control) and cultured in the presence or absence of putrescine $(5-500 \mu \mathrm{M})$ for 7 days and then counted as described in Materials and Methods. Results are mean \pm SD $(n=4)$, a indicates bars which are significantly different from control (DMSO without putrescine) group, $b$ indicates significant difference from the $13 \mathrm{C}$ alone treatment, and $\mathrm{c}$ indicates significant difference from the DFMO alone treatment $(\mathrm{P}<0.05)$. 
The cell lines also differed in their ability to recover from treatment with I3C (Fig 4). The HT29 cell line recovered completely from 24 hour treatment with I3C up to 500 $\mu \mathrm{M}$, and also recovered from combined I3C $(250 \mu \mathrm{M}) /$ putrescine $(500 \mu \mathrm{M})$ treatment. In contrast, SW480 cells only partially recovered from 24 hour treatment with I3C at $175 \mu \mathrm{M}$ in the presence or absence of putrescine (50 $\mu \mathrm{M})$, and were unable to recover from higher concentrations of I3C. The HCEC cell line behaved more like the HT29 line, but did not recover completely. The reason for this apparent difference in the ability of the two tumour cell lines to recover from treatment is not clear at the present time. However, these data may suggest that $\mathrm{I} 3 \mathrm{C}$ could be acting via different mechanisms, one reversible and one irreversible; alternatively, it is also possible that the effect is time dependent and that treatment with I3C for a longer period would have resulted in irreversible growth inhibition in the HT29 cell line also. We have previously observed a difference in the ability of two breast cell lines, HBL100 and MDA MB468 to recover from I3C treatment [67], which we concluded was related to the induction of apoptosis in the latter, but not in the former cell line.

\section{Effect of I3C and exogenous putrescine on induction of ap- optosis or cell cycle arrest}

In order to investigate whether I3C induces apoptosis in colon cells, and to address the possibility that the combination treatment of I3C plus putrescine may predispose SW480 cells to apoptosis, we compared levels of live, apoptotic and necrotic cells, determined by measurement of phosphatidylserine externalisation after treatment with I3C alone, I3C plus putrescine, or DFMO.

Treatment with I3C caused significant induction of apoptosis in the SW480 cell line at 250 and $500 \mu \mathrm{M}$ after 96 hour treatment, but only slight induction was apparent with $175 \mu \mathrm{M}$ (Fig 5). Induction of apoptosis was accompanied by an increase in necrotic cells, possibly due to secondary necrosis of previously apoptotic cells. It seems unlikely that the low level of apoptosis seen in response to $175 \mu \mathrm{M}$ I3C after 96 hours could account for the apparently irreversible nature of growth inhibition observed for this concentration in the SW480 cell line.

The combination treatment did not further induce apoptosis, but did cause a significant increase in the proportion of cells undergoing necrosis $(9.5 \%$ in the $\mathrm{I} 3 \mathrm{C}+$ putrescine treatment compared with $4 \%$ for I3C $175 \mu \mathrm{M}$ alone; $\mathrm{P}<$ $0.05)$. The effect of combination of putrescine with higher concentrations of I3C (250 or $500 \mu \mathrm{M})$ was not assessed due to the high level of toxicity encountered with the original combination treatment (I3C $175 \mu \mathrm{M}+$ putrescine). Putrescine alone had no effect on control cells. DFMO did not induce apoptosis or necrosis following treatment for 96 hours (data not shown).

We also investigated whether cell cycle arrest may contribute to the inhibition of cell growth at these concentrations. DFMO caused an increase in the proportion of cells in $G_{0} / G_{1}$ phase of the cell cycle in both tumour cell lines, as has been previously reported in other cell lines [7375]. No major phase specific block in cell cycle progression was observed following treatment with I3C alone or in combination with putrescine for 96 hours in either cell line. However, I3C caused a small but significant decrease in $G_{0} / G_{1}$, which was accompanied by an increase in the proportion of cells in $\mathrm{G}_{2} / \mathrm{M}$ in the SW480 cell line. Accumulation of cells in G2/M achieved significance in the I3C + putrescine treatment compared with control SW480 cells, but was not significantly elevated above levels of I3C treated cells (Fig. 6A). In order to further investigate this effect, cells were first synchronised in G2/M by treatment with nocodazole, and then released into either control or I3C \pm putrescine-treated medium. Neither I3C alone, nor in combination with putrescine caused a delay in exit of cells from G2/M, however, cells in both treatment groups appeared to accumulate in G2/M by 32 hours after release (Fig 6B). The agents did not prolong progression of cells through any phase of the cycle within 24 hours of release from nocodazole block.

\section{Modulation by I3C of intracellular polyamines and effect of exogenous putrescine in SW480 cells}

To investigate whether modulation of intracellular polyamine levels could be contributing to the sensitisation of the SW480 cells to I3C by putrescine, intracellular putrescine, spermidine and spermine levels were measured after treatment with $\mathrm{I} 3 \mathrm{C}$ in the presence or absence of putrescine. In control cells at the 24 hour time point, spermine was the most abundant of the polyamines analysed, occurring at levels approximately 1.5 and 4 fold higher than spermidine and putrescine respectively. Exposure to I3C for $24 \mathrm{hr}$ resulted in a significant decrease in intracellular putrescine levels, which was completely reversed by co-exposure of the cells to exogenous putrescine (Fig 7; Table 1). The I3C-induced decrease was transient, as by 96 hours of treatment, intracellular putrescine was found to be slightly raised above control levels. Levels of spermidine were not consistently altered at any time point during exposure to I3C (Table 1 ). In contrast, at each time point, levels of intracellular spermine were increased in cells treated with $\mathrm{I} 3 \mathrm{C}$ concentrations that caused a decrease in cell number (Fig. 8), indicating a possible inverse relationship between spermine accumulation and cell growth. While co-administration of exogenous putrescine restored intracellular putrescine levels to normal, it did not alter intracellular levels of spermine in control cells, or prevent the accumulation of spermine in I3C-treated cells 


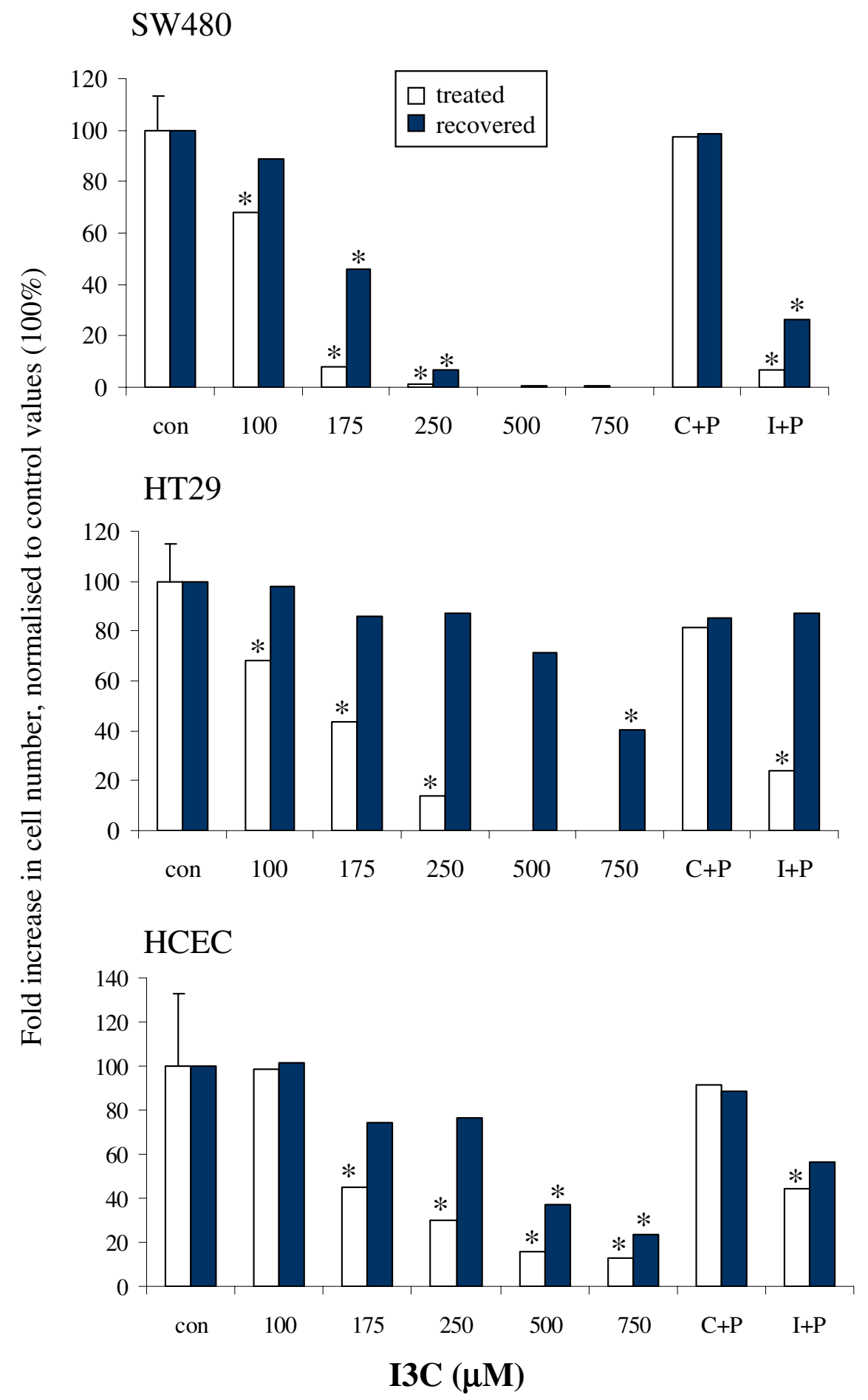

\section{Figure 4}

Recovery of cells from 24 hour treatment with I3C. Cells were cultured in the presence of I3C for 24 hours, after which cells were either maintained in $13 \mathrm{C}$-containing medium or replenished with fresh medium and allowed to recover, as described in Materials and Methods. Cell proliferation is expressed as a \% of the control values, data are presented as mean \pm pooled SD (shown on control bar only; $n=3$ ). Significant difference from the control (DMSO treated) is indicated by $*(P<$ 0.05). 


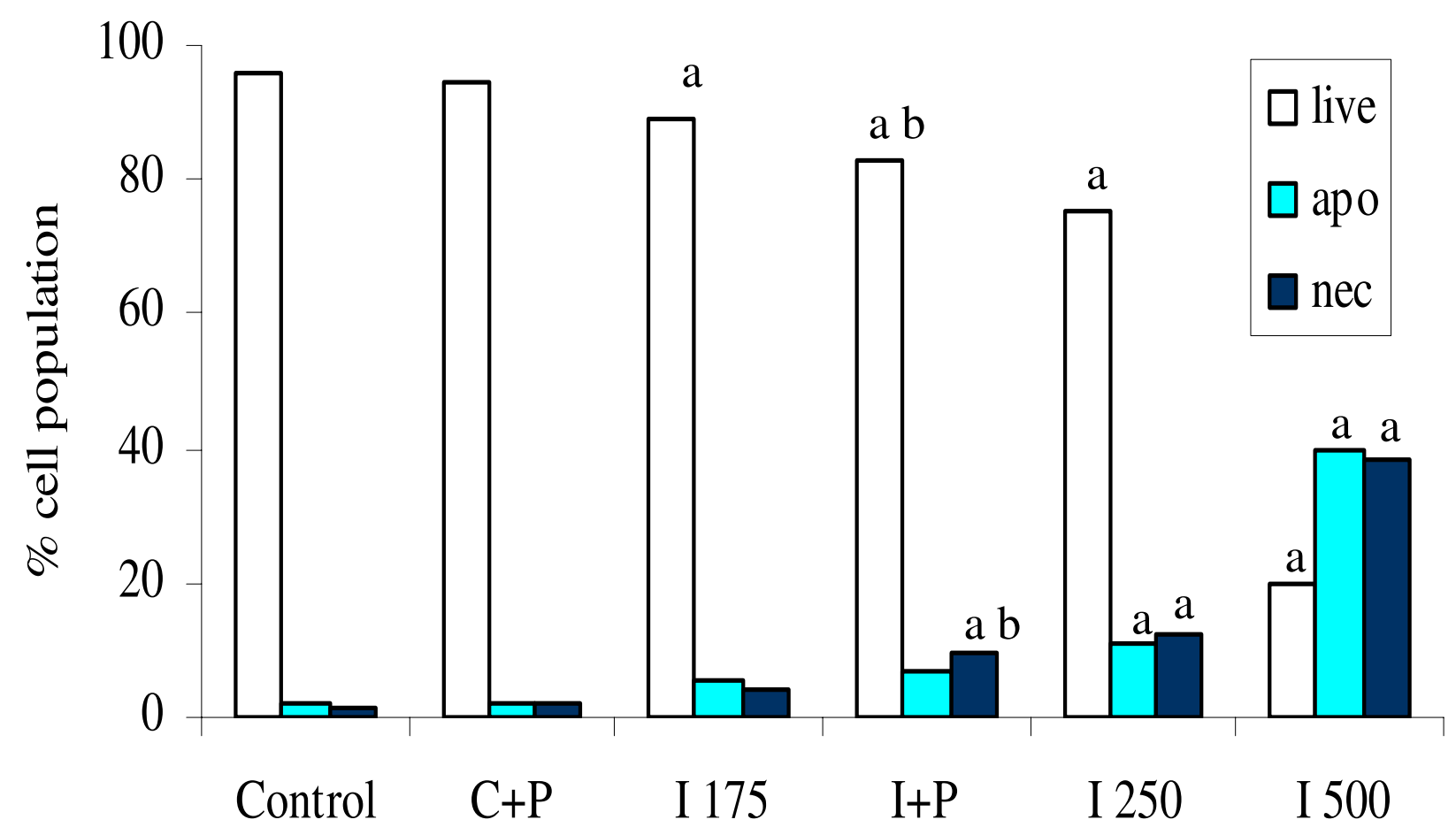

Figure 5

Induction of apoptosis or necrosis in SW480 cells by I3C in the presence or absence of putrescine. Cells were treated for 96 hours and then harvested and stained for phosphatidylserine externalisation and propidium iodide incorporation before analysis by flow cytometry as described in Materials and Methods. Control = DMSO treated cells, C+P = DMSO plus putrescine $(50 \mu \mathrm{M}), \mathrm{II} 75,1250,1500=\mathrm{I} \mathrm{C}$ (at the given concentration) and I+P = I3C (I75 $\mu \mathrm{M})$ plus putrescine. Significant difference from control is indicated by a, and between the I3C I75 $\mu$ M and I3C + putrescine treatment by $b(P<0.05)$. Results are displayed as means $(n=12)$, pooled $S D=6.08$.

(data not shown). The total intracellular level of the three polyamines was also increased in response to I3C, in a pattern corresponding with that of the major component, spermine.

In a preliminary experiment (assays performed in duplicate) intracellular levels of GSH were determined in extracts from cells treated for either 24,96 or 168 hours. No evidence for a decrease in GSH level was obtained with any treatment at any of the time points (data not shown).

\section{Effect of I3C on uptake of putrescine by SW480 cells}

In order to further investigate the effect of I3C on regulation of the intracellular putrescine pool, we determined putrescine uptake following treatment with I3C alone or in medium supplemented with putrescine. SW480 cells which had been treated with I3C under normal growth conditions for 24 hours exhibited a 50\% decrease in the rate of putrescine uptake (Fig 9), which appeared to correlate with the decrease in intracellular putrescine levels shown in Fig 7. DFMO increased the rate of putrescine uptake 2.5-fold over control levels (Fig 9).

\section{Discussion}

Upregulation of ODC has been implicated as a necessary and early step in carcinogenesis. The ability of some chemopreventive agents, such as DFMO, to inhibit ODC activity is therefore thought to be an important mechanistic 

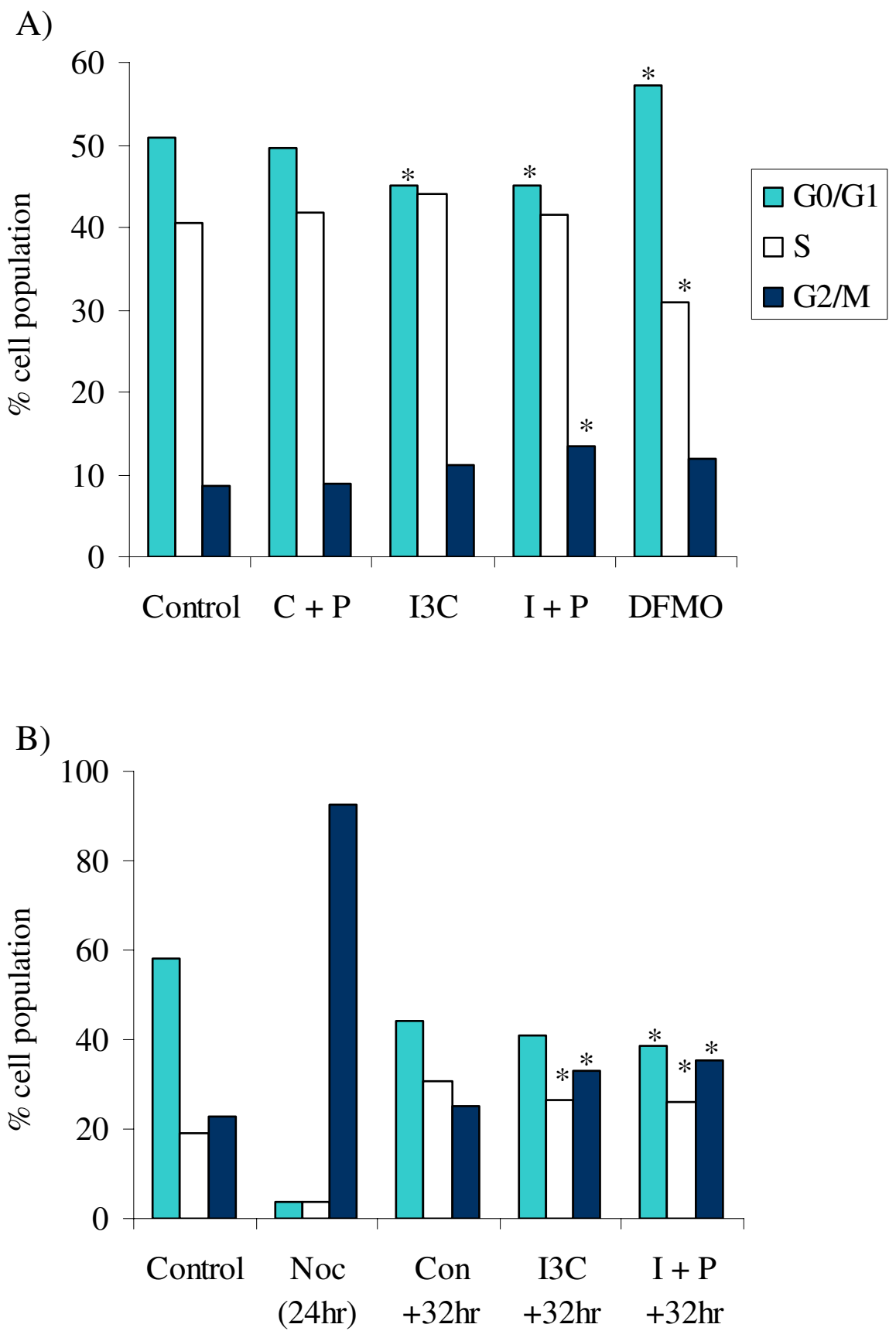

\section{Figure 6}

Effect of I3C in the presence or absence of putrescine on progression of SW480 cells through the cell cycle. A) Cells were treated for 96 hours as indicated, and stained with propidium iodide before analysis by flow cytometry as described in Materials and Methods. Control $=\mathrm{DMSO}$ treated cells, $\mathrm{C}+\mathrm{P}=\mathrm{DMSO}$ plus putrescine $(50 \mu \mathrm{M}), \mathrm{I} \mathrm{C}=\mathrm{I} \mathrm{C}(\mathrm{I} 75 \mu \mathrm{M})$ and I+P $=13 \mathrm{C}(\mathrm{I} 75 \mu \mathrm{M})$ plus putrescine, DFMO = DFMO $(50 \mu \mathrm{M})$. * indicates a significant difference from control levels $(\mathrm{P}<0.05 ; \mathrm{n}=$ 8; pooled SD = 3.54). B) Cells were synchronised with nocodazole for $24 \mathrm{hr}$ (Noc (24 hr)) and then released into control (Con $+32 \mathrm{hr})$, I3C (I3C +32 hr) or I+P (I+P +32 hr) treated medium and analysed as described in Materials and Methods. Data from the $+32 \mathrm{hr}$ time point is shown. Control $=$ DMSO treated, non-synchronised cells. * indicates a significant difference from the Con $+32 \mathrm{hr}$ value for each phase of the cell cycle $(P<0.05 ; n=4$; pooled $S D=2.6 \mathrm{I})$. 


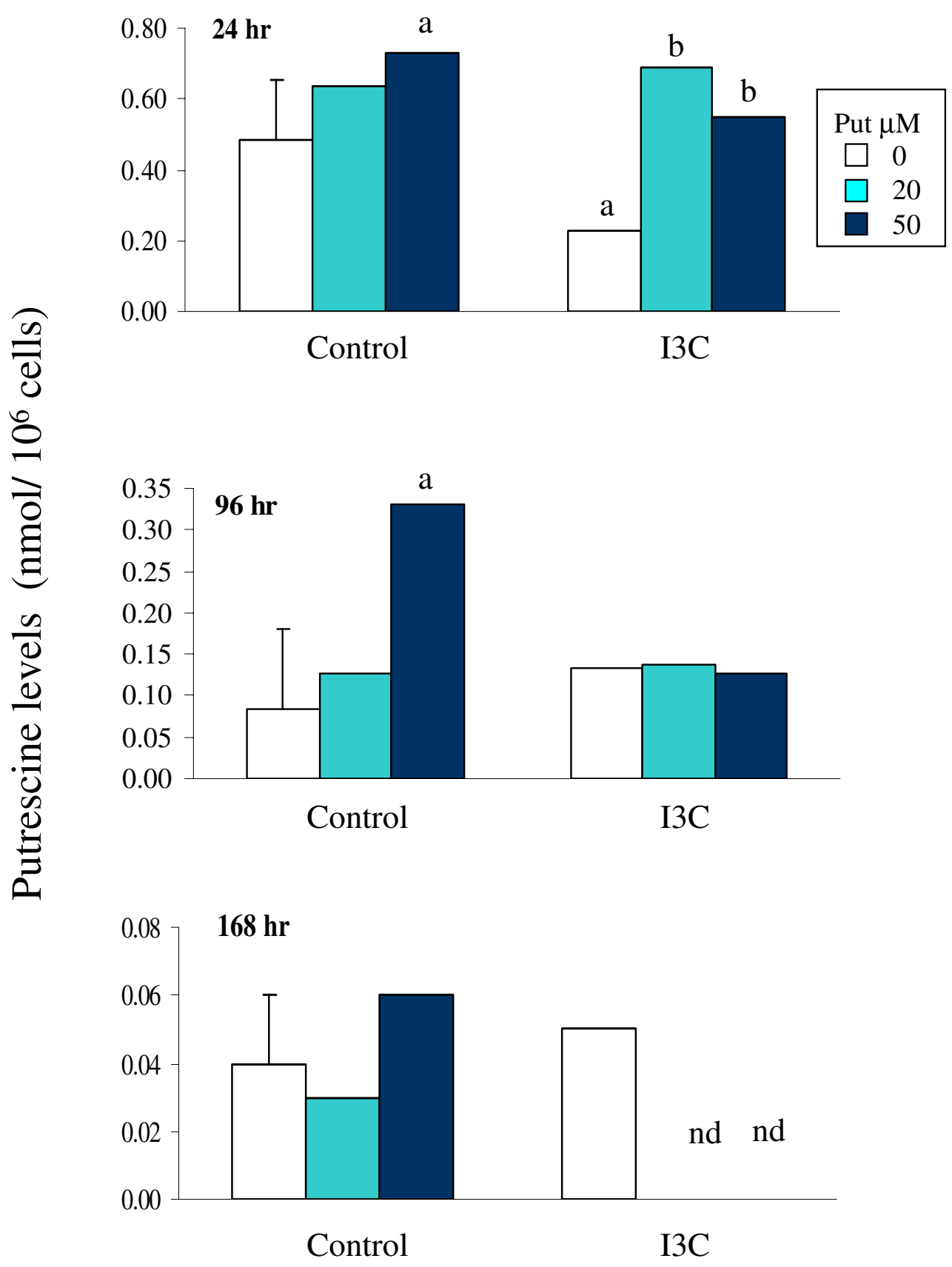

Figure 7

Effect of I3C in the presence or absence of putrescine on intracellular putrescine levels in SW480 cells following 24 hour treatment. Cells were cultured with DMSO alone (Control) or I3C (I75 $\mu \mathrm{M}$ ) in the presence of 0,20 or $50 \mu \mathrm{M}$ putrescine as indicated. Intracellular putrescine levels were determined by HPLC, as described in Materials and Methods.

Results are presented as mean \pm pooled SD (shown on control bar only, $n=4$ ). nd = value not determined. Significant difference from the control (DMSO without putrescine), and from I3C without putrescine, is indicated by a and ${ }^{b}$ respectively $(P<$ 0.05). 

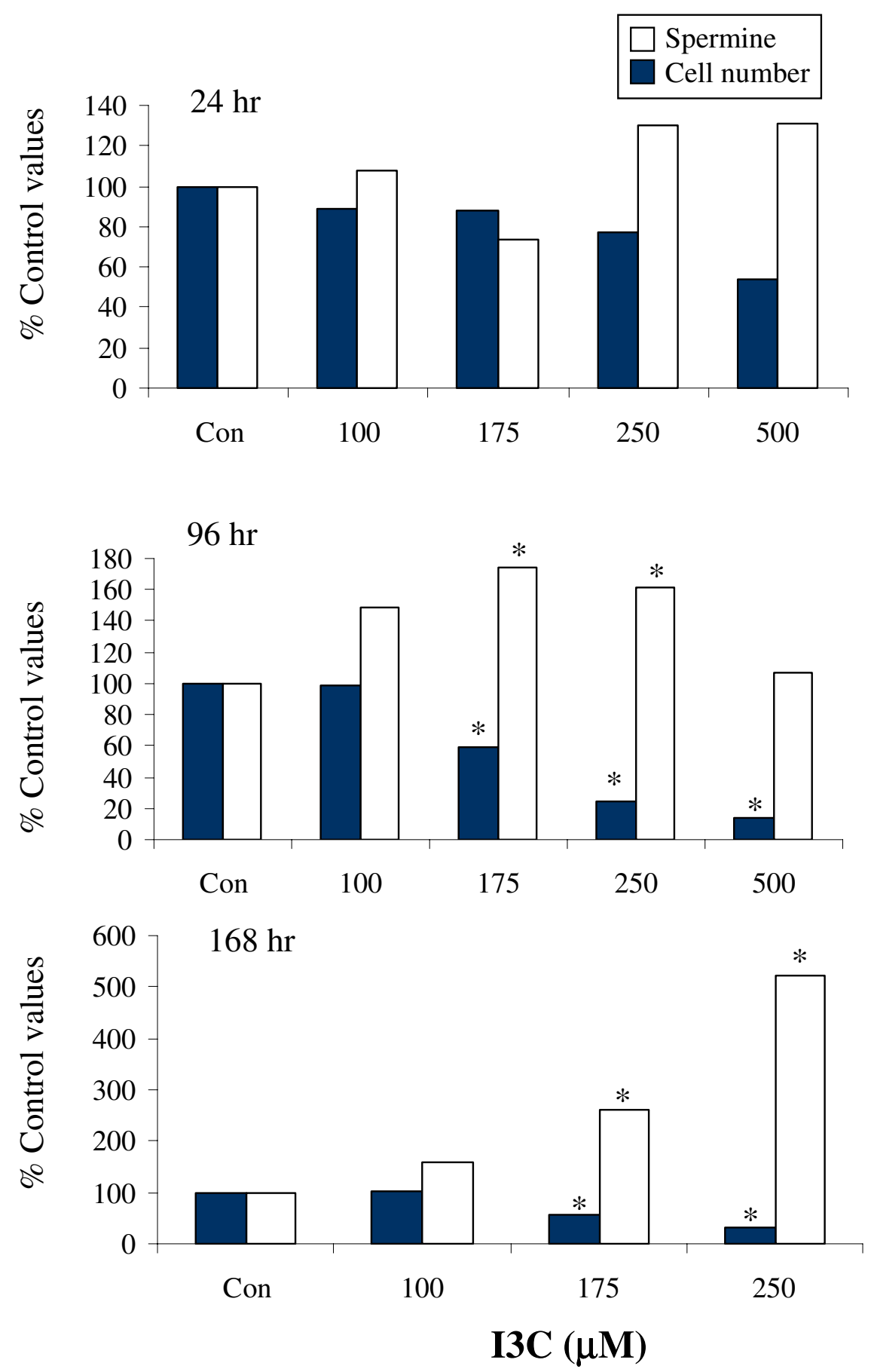

Figure 8

Effect of I3C on cell number and intracellular spermine levels in SW480 cells after 24, 96 or I68 hour treatments. Cells were treated with DMSO alone (Con) or I3C as indicated, and intracellular spermine levels were determined by HPLC, as described in Materials and Methods. Results are presented as percentage of control values (mean $n=4$; $*$ indicates significant difference from control levels $(P<0.05)$; pooled $S D=0.8,0.6, I . I$ and $24.4, I I .8,12.0$ for spermine levels and cell numbers respectively at 24,96 and 168 hours). The mean spermine concentration (nmol// $10^{6}$ cells) in control cells at 24,96 and $168 \mathrm{hr}$ was $2.10,1.25$ and 0.76 respectively. 
Table I: Effect of I3C alone and in combination with putrescine on intracellular polyamine levels at 24,96 and 168 hours.

\begin{tabular}{|c|c|c|c|c|}
\hline Treatment & Cell no. as \% Control (SD) & Putrescine (SD) & Spermidine (SD) & Spermine (SD) \\
\hline \multicolumn{5}{|l|}{24 hour } \\
\hline Control & $100.0(0.0)$ & $0.48(0.3 \mathrm{I})$ & $1.62(0.55)$ & $2.10(0.98)$ \\
\hline $13 \mathrm{C} 100$ & $89.1(19.8)$ & $0.31(0.09)$ & $\mathrm{I} .79(0.5 \mathrm{I})$ & $2.25(1.21)$ \\
\hline I3C I75 & $87.9(29.2)$ & $0.23(0.06)^{*}$ & $1.32(0.36)$ & $1.54(0.19)$ \\
\hline I3C 250 & $77.4(32.7)$ & $0.19(0.04)^{*}$ & $2.17(0.98)$ & $2.73(1.86)$ \\
\hline I3C 500 & $54.2(26.6)$ & $0.14(0.07)^{*}$ & $1.57(0.60)$ & $2.74(1.82)$ \\
\hline$C+P 20$ & $96.9(23.5)$ & $0.64(0.26)$ & $2.17(1.06)$ & $2.41(1.53)$ \\
\hline$C+P 50$ & $90.0(42.1)$ & $0.72(0.27)^{*}$ & $2.34(\mathrm{I} .48)$ & $2.59(1.93)$ \\
\hline $\mathrm{I}+\mathrm{P} 20$ & $76.2(26.3)$ & $0.69(0.29)$ & $2.93(1.57)^{*}$ & $3.06(1.99)$ \\
\hline$I+P 50$ & $76.1(35.0)$ & $0.54(0.16)$ & $1.86(0.49)$ & $1.94(0.65)$ \\
\hline \multicolumn{5}{|l|}{96 hour } \\
\hline Control & $100.0(0.0)$ & $0.08(0.04)$ & $0.79(0.30)$ & $1.25(0.38)$ \\
\hline $13 C 100$ & $98.7(8.5)$ & $0.13(0.09)$ & I.II (0.40) & $1.87(0.47)$ \\
\hline $13 C 175$ & $58.9(3.8)$ & $0.13(0.10)$ & $0.98(0.29)$ & $2.18(0.79)^{*}$ \\
\hline I3C 250 & $24.9(6.1)$ & $0.15(0.11)$ & $0.77(0.36)$ & $2.03(1.17)^{*}$ \\
\hline I3C 500 & $13.9(6.0)$ & nd & $0.62(0.32)$ & $1.34(0.45)$ \\
\hline$C+P 20$ & $96.6(12.4)$ & $0.13(0.03)$ & $0.84(0.15)$ & $1.15(0.12)$ \\
\hline$C+P 50$ & $79.2(14.3)$ & $0.32(0.18)^{*}$ & $1.47(0.15)^{*}$ & $1.98(0.34)$ \\
\hline $\mathrm{I}+\mathrm{P} 20$ & $28.1(22.6)$ & $0.17(0.09)$ & $1.25(0.23)^{*}$ & $2.42(0.21)^{*}$ \\
\hline I + P50 & $17.9(2.9)$ & $0.11(0.02)$ & $0.80(0.21)$ & $1.54(0.48)$ \\
\hline \multicolumn{5}{|l|}{168 hour } \\
\hline Control & $100.0(0.0)$ & $0.04(0.02)$ & $0.46(0.07)$ & $0.76(0.17)$ \\
\hline $13 \mathrm{C} 100$ & $104.0(9.9)$ & $0.03(0.01)$ & $0.57(0.25)$ & $1.22(0.32)$ \\
\hline I3C I75 & $57.1(9.5)$ & $0.05(0.03)$ & $0.62(0.28)$ & $1.99(0.96)^{*}$ \\
\hline I3C 250 & $31.1(20.2)$ & $0.07(0.01)$ & $0.87(0.54)$ & $2.93(0.72)^{*}$ \\
\hline I3C 500 & $4.5(5.2)$ & nd & nd & nd \\
\hline$C+P 20$ & $107.2(4.8)$ & $0.03(0.01)$ & $0.48(0.04)$ & $0.83(0.15)$ \\
\hline$C+P 50$ & $104.5(10.1)$ & $0.06(0.04)$ & $0.67(0.10)$ & $1.08(0.19)$ \\
\hline $\mathrm{I}+\mathrm{P} 20$ & $6.0(5.5)$ & nd & $0.91(0.55)$ & $3.11(1.59)^{*}$ \\
\hline $1+P 50$ & $3.0(0.7)$ & nd & $0.90(0.56)$ & $2.26(1.42)^{*}$ \\
\hline
\end{tabular}

Cells were treated with $13 \mathrm{C}$ alone or in combination with putrescine, and intracellular polyamines determined as described in the Methods Section. Data shown for cell numbers are expressed as a \% Control, and polyamine levels are nmol/ $/ 0^{6}$ cells. All values are means with SD in brackets. nd $=$ values not determined. * indicates a value that is significantly different to the control value at that time point.

contributor to their anticarcinogenicity. The results described above show for the first time that in colon cancer cells I3C decreases ODC activity and interferes with intracellular polyamine levels. However, there are intriguing differences between I3C and the classical ODC inhibitor, DFMO. Consistent with the known mechanism of action of DFMO, exogenously added putrescine antagonised growth inhibition caused by this agent. In contrast, while I3C also reduced ODC activity and decreased intracellular putrescine levels, its growth-inhibitory effect was not reversed, and in the case of the SW480 cell line, was actually increased in the presence of exogenous putrescine. This led us to conclude that in the colon tumour cells studied here, the growth inhibitory effect of I3C appeared to be independent of its ability to decrease intracellular putrescine levels. This conclusion is further supported by the observation that exogenously added putrescine restored intracellular putrescine levels of I3C-treated cells to normal. It is worthy of note, that while exogenously added putrescine can reverse growth inhibition due to impaired polyamine synthesis, it cannot reverse growth inhibition caused by altered polyamine catabolism or efflux.

It is possible that the decrease in putrescine observed at the initial time point, was not wholly due to inhibition of ODC activity or decreased uptake, but also due to the continued conversion of the diamine to spermidine, levels of which did not fall in response to I3C treatment. Putrescine levels in SW480 cells were also found to have reverted to control levels after 96 hours of treatment with I3C alone indicating that the cells overcome these initial effects of I3C observed at 24 hours. Several possibilities may account for this, including reversal of the inhibition of ODC activity and/or putrescine uptake observed after 24 hour treatment. I3C treatment of SW480 cells resulted in an accumulation of intracellular spermine over time (up to approximately 5 fold above control levels), which 


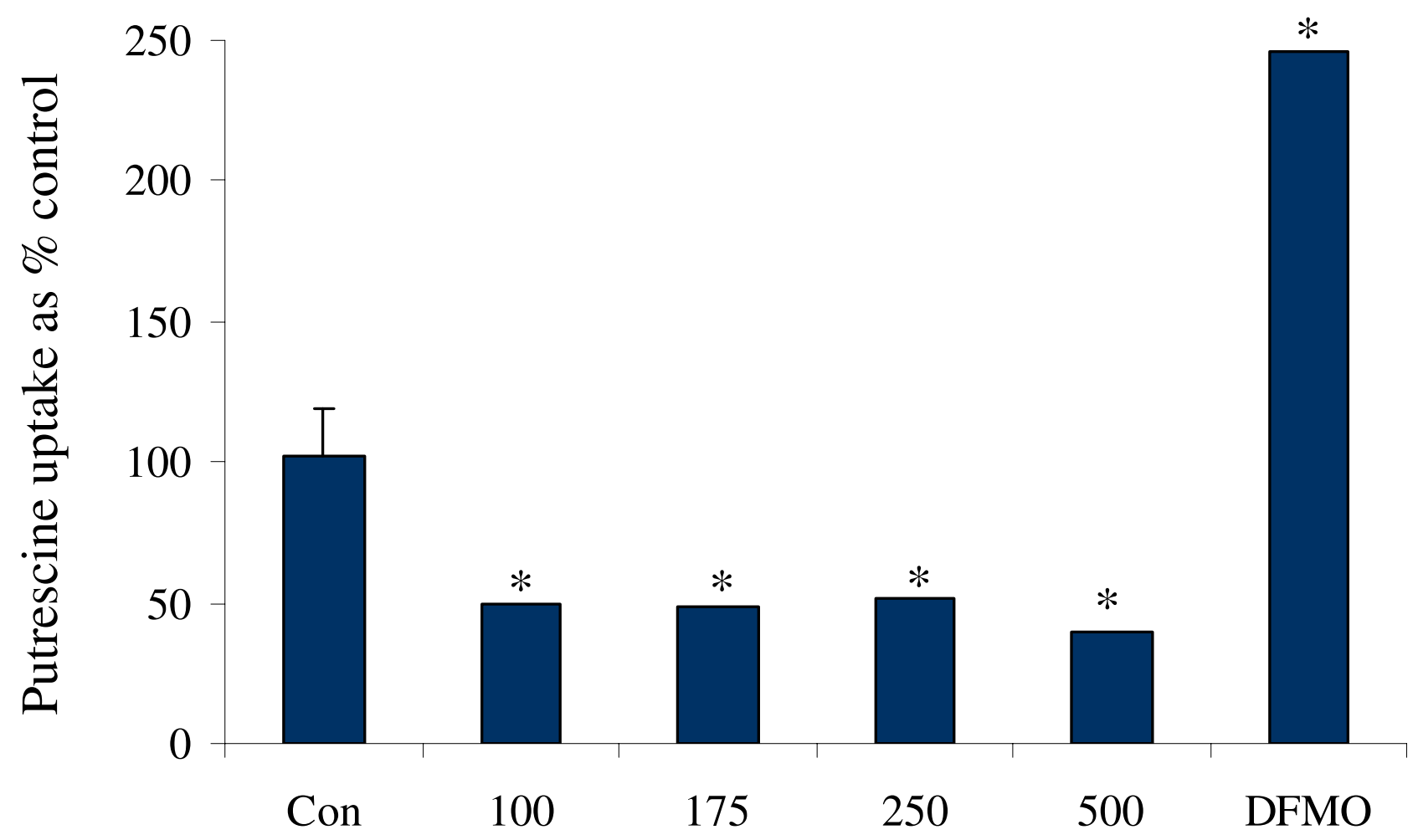

\section{$\mathrm{I} 3 \mathrm{C}(\mu \mathrm{M})$}

\section{Figure 9}

Effect of I3C on putrescine uptake in SW480 cells. Cells were treated with DMSO alone (Con), I3C or DFMO as indicated, and putrescine uptake determined as described in Materials and Methods. Results are presented as percentage of control values $(n=$ minimum of 4$) *$ indicates significant difference from control levels $(P<0.05)$.

corresponded with a dose dependent decrease in cell number at each time point.

There are many reports in the literature detailing the cytotoxic effects of spermine [76-81], although it should be noted that high concentrations of exogenous spermine were used in these studies. It is possible that the accumulation of spermine seen in response to treatment with I3C contributes to its growth-inhibitory action in this cell line. Addition of exogenous putrescine, did not prevent (nor significantly increase), the accumulation of intracellular spermine levels observed in response to treatment with I3C, which may explain, at least in part, the inability of exogenous putrescine to prevent the I3C-induced growth in- hibition. Several mechanisms have been proposed for the cytotoxicity of spermine, including competition for spermidine and $\mathrm{Mg} 2+$ binding sites, thus preventing many of the physiological functions of spermidine and $\mathrm{Mg} 2+$, such as protein synthesis, as well as loss of intracellular glutathione through conjugation or spermine-induced oxidative stress, or a direct toxic effect of the spermine itself $[78,80,81]$. In preliminary experiments we found no evidence of a decrease in intracellular GSH levels following any treatment.

Seiler et al. [76] have reported a non-apoptotic mechanism of cell death in CaCo-2 cells that had accumulated high levels of spermine (more than double normal lev- 
els). In that study, exposure to $5 \mathrm{mM}$ spermine caused a decrease in the population of cells in $G_{1}$, and an accumulation in the $G_{2}$ phase of the cell cycle [76]. In our study, at higher concentrations $(\geq 250 \mu \mathrm{M})$, I3C caused induction of apoptosis accompanied by necrosis, but only a small increase in either was observed at the 96 hour time point with $175 \mu \mathrm{M}$ I3C, and although we did not obtain a clear phase specific arrest with any treatment in our study, the proportion of cells in $\mathrm{G}_{1}$ decreased and the number in $\mathrm{G}_{2} / \mathrm{M}$ increased in response to I3C from 32 hours. In the combination treatment (I3C + putrescine), the number of cells in $\mathrm{G}_{2} / \mathrm{M}$ was slightly increased and the proportion of cells undergoing necrosis was significantly increased compared with I3C treatment alone. Although each of these changes appears to be small when considered in isolation, in combination they may be sufficient to account for the inhibition caused by I3C in the cell growth experiments. At $96 \mathrm{hr}$, control cells showed combined apoptosis + necrosis of less than $4 \%$, with approximately $8 \%$ of cells in $\mathrm{G}_{2} / \mathrm{M}$; I3C (175 $\left.\mu \mathrm{M}\right)$-treated cells showed combined apoptotic and necrotic cells of $9 \%$, with $11 \%$ in $\mathrm{G}_{2} / \mathrm{M}$, while of $\mathrm{I} 3 \mathrm{C}+$ putrescine-treated cells, approximately $16 \%$ were undergoing apoptosis or necrosis, with $13 \%$ in $\mathrm{G}_{2} / \mathrm{M}$.

The mechanism by which I3C inhibited ODC activity was not further investigated in this study, but clearly occurs at a level distinct from the direct enzyme inhibition caused by DFMO. ODC activity can be regulated via many signalling pathways, including the epidermal growth factor receptor, PI3K, and estrogen receptor pathways [41-44], which are potential targets for the action of chemopreventive agents such as I3C. We have shown, for example, that I3C can inhibit the $\mathrm{PI} 3 \mathrm{~K} /$ protein kinase $\mathrm{B}$ pathway in the MDA MB468 breast tumour cell line, but not in the normal derived HBL100 line [67], but this did not correlate with the ability of this agent to inhibit ODC activity in those cell lines (Howells L.M. et al. unpublished data). There are clearly multiple possible mechanisms via which I3C could exert its effect on ODC activity in these colon cell lines, including inhibition of signalling pathways such as those mentioned above.

\section{Conclusions}

Our conclusion from this work is that inhibition of ODC activity and consequent decrease in intracellular putrescine levels does not, per se, constitute a primary mechanism of action of I3C in these colon cell lines. However, perturbation of polyamine homeostasis leading to increases in intracellular spermine levels may contribute to a cytotoxic effect of the agent. The exact mechanism by which putrescine sensitised the SW480 cell line to I3C has not yet been elucidated, and the relevance of this observation to future chemopreventive strategies involving I3C remains to be determined.

\section{Competing interests}

None declared.

\section{Authors' contributions}

EAH conceived of the study, and participated in its design and coordination, drafted the manuscript, and carried out the experimental work except as follows. LMH contributed to the proliferation and ODC activity studies. BG-H contributed to the apoptosis studies. LHF contributed to the proliferation studies. AG and MMM participated in the design and coordination of the study. All authors read and approved the final manuscript.

\section{List of Abbreviations}

DFMO, Difluoromethylornithine; I3C, Indole-3-carbinol; ODC, Ornithine decarboxylase; PI3K, phospho-inositide 3-kinase.

\section{Acknowledgements}

We would like to thank Drs Andrea Pfeifer and Elizabeth Offord (Nestle Ltd. Research Centre, Lausanne 26, Switzerland), for the generous gift of the HCEC cell line.

\section{References}

I. Jellinck PH, Forkert P-G, Riddick DS, Okey AB, Michnovicz JJ and Bradlow $\mathrm{HL}$ Ah receptor binding properties of indole carbinols and induction of hepatic estradiol hydroxylation. Biochem Pharmacol 1993, 45: I I29-II36

2. Bradlow HL, Michnovicz J], Halper M, Miller DG, Wong GYC and Osborne MP Long-term responses of women to indole-3-carbinol or a high fiber diet. Cancer Epidemiol Biomarkers Prev 1994, 3:59|-595

3. Telang NT, Katdare M, Bradlow HL, Osborne MP and Fishman J Inhibition of proliferation and modulation of estradiol metabolism: novel mechanisms for breast cancer prevention by the phytochemical indole-3-carbinol. Proc Soc Exp Biol Med 1997, 216:246-252

4. Wong GYC, Bradlow L, Sepkovic D, Mehl S, Mailman J and Osborne MP Dose-ranging study of indole-3-carbinol for breast cancer prevention. J Cell Biochem Suppl 1997, 28/29: I I I-I I6

5. Rosen CA, Woodson GE, Thompson JW, Hengesteg AP and Bradlow $\mathrm{HL}$ Preliminary results of the use of indole-3-carbinol for recurrent respiratory papillomatosis. Otolaryngol Head Neck Surg 1998, I 1 8:810-815

6. Bell MC, Crowley-Nowick P, Bradlow HL, Sepkovic DW, SchmidtGrimminger D, Howell P, Mayeaux E], Tucker TE, Turbat-Herrera EA and Mathis JM Placebo-controlled trial of indole-3-carbinol in the treatment of CIN. Gynaecologic Oncology 2000, 78:123-129

7. Manson MM, Hudson EA, Ball HWL, Barrett MC, Clark HL, Judah DJ, Verschoyle RD and Neal GE Chemoprevention of aflatoxin $\mathbf{B}_{\mathbf{I}}-$ induced carcinogenesis by indole-3-carbinol in rat liver - predicting the outcome using early biomarkers. Carcinogenesis 1998, 19:1829-1836

8. Tanaka T, Kojima T, Morishita $Y$ and Mori $H$ Inhibitory effects of the natural products indole-3-carbinol and sinigrin during initiation and promotion phases of 4-nitroquinoline I-oxide-induced rat tongue carcinogenesis. Jpn J Cancer Res 1992, 83:835842

9. Srivastava $B$ and Shukla $Y$ Antitumour promoting activity of indole-3-carbinol in mouse skin carcinogenesis. Cancer Lett 1998, 134:91-95

10. Grubbs CJ, Steele VE, Casebolt T, Juliana MM, Eto I, Whitaker LM, Dragnev KH, Kelloff GJ and Lubet RL Chemoprevention of chemically-induced mammary carcinogenesis by indole-3-carbinol. Anticancer Res 1995, 15:709-716

II. Xu M, Orner GA, Bailey GS, Stoner GD, Horio DT and Dashwood RH Post-initiation effects of chlorophyllin and indole-3-carbi- 
nol in rats given 1,2-dimethylhydrazine or 2-amino-3-methyl-imidazo [4,5-f]quinoline. Carcinogenesis 200I, 22:309-3।4

12. Stoner GD, Casto B, Ralston S, Roebuck B, Pereira C and Bailey G Development of a multi-organ rat model for evaluating chemopreventive agents: efficacy of indole-3-carbinol. Carcinogenesis 2002, 23:265-272

13. Bailey GS, Hendricks JD, Shelton DW, Nixon JE and Pawlowski N Enhancement of carcinogenesis by the natural anti-carcinogen indole-3-carbinol. J Natl Cancer Inst 1987, 78:93I-934

14. Dashwood RH, Fong AT, Williams DE, Hendricks JD and Bailey GS Promotion of aflatoxin $B_{\text {I }}$ carcinogenesis by the natural tumor modulator indole-3-carbinol: influence of dose duration, and intermittent exposure on indole-3-carbinol promotional potency. Cancer Res I99।, 5 I:2362-2365

15. Kim DJ, Lee KK, Han BS, Ahn B, Bae JH and Jang |J Biphasic modifying effect of indole-3-carbinol on diethylnitrosamine-induced preneoplastic glutathione S-transferase placental form-positive liver-cell foci in Sprague Dawley rats. Jpn J Cancer Res 1994, 85:578-583

16. Goeger DE, Shelton DW, Hendricks JD and Bailey GS Mechanisms of anti-carcinogenesis by indole-3-carbinol: effect on the distribution and metabolism of aflatoxin $B_{\mid}$in rainbow trout. Carcinogenesis 1986, 7:2025-2031

17. Dashwood RH, Arbogast DN, Fong AT, Hendricks JD and Bailey GS Mechanisms of anti-carcinogenesis by indole-3-carbinol: detailed in vivo DNA binding dose-response studies after dietary administration with aflatoxin $B_{1}$. Carcinogenesis 1988, 9:427-432

18. Dashwood RH, Arbogast DN, Fong AT, Pereira C, Hendricks JD and Bailey GS Quantitative inter-relationships between aflatoxin

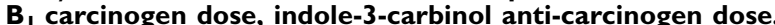
target organ DNA adduction and final tumour response. Carcinogenesis 1989, 10:175-181

19. Stresser DM, Bailey GS and Williams DE Indole-3-carbinol and $\beta$ naphthoflavone induction of aflatoxin $B_{\mid}$metabolism and cytochromes $\mathbf{P 4 5 0}$ associated with bioactivation and detoxification of aflatoxin $\mathbf{B}_{\mathbf{I}}$ in the rat. Drug Metab Disp 1994, 22:383391

20. Stresser M, Williams DE, McLellan LI, Harris TM and Bailey GS Indole-3-carbinol induces a rat-liver glutathione transferase subunit (Yc2) with high activity toward aflatoxin $B_{\mid}$exoepoxide - association with reduced levels of hepatic aflatoxin DNA adducts in vivo. Drug Metab Disp 1994, 22:392-399

21. Hayes JD, Judah DJ, McLellan LI and Neal GE Contribution of glutathione S-transferases to the mechanisms of resistance to aflatoxin B . Pharmacol Ther 1991, 50:443-472

22. Judah DJ, Hayes JD, Yang J-C, Lian L-Y, Roberts GCK, Farmer PB, Lamb $\mathrm{JH}$ and Neal GE A novel aldehyde reductase with activity towards a metabolite of aflatoxin $B_{\mid}$, is expressed in rat liver during carcinogenesis and following the administration of an antioxidant. Biochem J 1993, 292:13-18

23. He Y-H, Friesen MD, Ruch RJ and Schut HA Indole-3-carbinol as a chemopreventive agent in 2-amino-I-methyl-6-phenylimidazo[4,5-b]pyridine (PhIP) carcinogenesis: Inhibition of PhIPDNA adduct formation, acceleration of PhIP metabolism, and induction of cytochrome P450 in female F344 rats. Food Chem Toxicol 2000, 38:15-23

24. Pegg AE Polyamine metabolism and its importance in neoplastic growth and as a target for chemotherapy. Cancer Res 1988, 48:759-774

25. Mohan RR, Challa A, Gupta S, Bostwick DG, Ahmad N, Agarwal R, Marengo SR, Amini SB, Paras F, MacLennan GT, Resnick MI and Mukhtar $\mathrm{H}$ Overexpression of ornithine decarboxylase in prostate cancer and prostatic fluid in humans. Clin Cancer Res $1999,5: 143-147$

26. Giardiello FM, Hamilton SR, Hylind LM, Yang VW, Tamez P and Casero RA Jr Ornithine decarboxylase and polyamines in familial adenomatous polyposis. Cancer Res 1997, 57:199-201

27. Manni A, Mauger D, Gimotty P and Badger B Prognostic influence on survival of increased ornithine decarboxylase activity in human breast cancer. Clin Cancer Res 1996, 2:190I-1906

28. Smith MK, Goral MA, Wright JH, Matrisian LM, Morris RJ, Klein-Szanto AJP and Gilmour SK Ornithine decarboxylase overexpression leads to increased epithelial tumor invasiveness. Cancer Res 1997, 57:2104-2108
29. O'Brien TG, Megosh LC, Gilliard G and Peralta Soler A Ornithine decarboxylase overexpression is a sufficient condition for tumor promotion in mouse skin. Cancer Res 1997, 57:2630-2637

30. Auvinen M, Laine A, Paasinen-Sohns A, Kangas A, Kangas L, Saksela $\mathrm{O}$, Anderson LC and Holtta E Human ornithine decarboxylaseoverproducing NIH3T3 cells induce rapidly growing, highly vascularised tumors in nude mice. Cancer Res 1997, 57:30163025

31. Auvinen M, Paasinen A, Andersson LC and Holtta E Ornthine decarboxylase activity is critical for cell transformation. Nature 1992, 360:355-358

32. Pegg $A E$, Shantz LM and Coleman CS Ornithine decarboxylase: Structure, function and translational regulation. Biochem Soc Trans 1994, 22:846-852

33. Kubota S Ornithine decarboxylase and cancer. Cancer J 1998, I I:294-297

34. Kameji T, Hayashi S-I, Hoshino K, Kakinuma $Y$ and Igarashi K Multiple regulation of ornithine decarboxylase in enzyme-overproducing cells. Biochem J 1993, 289:58I-586

35. Murakami Y, Matsufuji S, Hayashi S-I, Tanahashi N and Tanaka K Degradation of ornithine decarboxylase by the $26 \mathrm{~S}$ proteasome. Biochem Biophys Res Comm 2000, 267:1-6

36. Shantz LM and Pegg AE Overproduction of ornithine decarboxylase caused by relief of translational repression is associated with neoplastic transformation. Cancer Res 1994, 54:23।3-23।6

37. Moshier JA, Osborne DL, Skunca M, Dosescu J, Gilbert JD, Fitzgerald MC, Polidori G, Wagner RL, Friezner Degen SJ, Luk GD and Flanagan MA Multiple promoter elements govern expression of the human ornithine decarboxylase gene in colon carcinoma cells. Nucl Acids Res 1992, 20:258I-2590

38. Moshier JA, Skunca M, Wu W, Boppana SM, Rauscher FJ III and Dosescu J Regulation of ornithine decarboxylase gene expression by the Wilms' tumor suppressor WTI. Nucl Acids Res 1996, 24: I I49-I I 57

39. Li R-S, Law GL, Seifert RA, Romaniuk PJ and Morris DR Ornithine decarboxylase is a transcriptional target of tumor suppressor WTI. Exp Cell Res 1999, 247:257-266

40. Kumar AP and Butler AP Transcription factor Sp3 anatagonizes activation of the ornithine decarboxylase promoter by $\mathrm{SpI}$. Nucl Acids Res 1997, 25:2012-2019

4I. Xue GZ, Zheng ZS, Chen RZ, Lloyd MB and Prystowsky JH Phorbol I2-myristate 13-acetate inhibits epidermal growth factor signalling in human keratinocytes, leading to decreased ornithine decarboxylase activity. Biochem J 1996, 3 1 9:64I-648

42. Ishikawa T, Ichikawa Y, Tarnawski A, Fujiwara Y, Fukuda T, Arakawa $T$, Mitsuhashi $M$ and Shimada $H$ Indomethacin interferes with EGF-induced activation of ornithine decarboxylase in gastric cancer cells. Digestion 1998, 59:47-52

43. Flamigni F, Marmiroli S, Capanni C, Stefanelli C, Guarnieri $C$ and Caldarera CM Phoshpatidylinositol 3-kinase is required for the induction of ornithine decarboxylase in leukemia cell stimulated to growth. Biochem Biophys Res Comm 1997, 239:729-733

44. Huber $M$ and Poulin R Posttranslational cooperativity of ornithine decarboxylase induction by estrogens and peptide growth-factors in human breast-cancer cells. Mol Cell Endocrinol 1996, II 7:211-218

45. Benamouzig R, Mahé S, Luengo C, Rautureau J and Tomé D Fasting and postprandial polyamine concentrations in the human digestive lumen. Am I Clin Nutr 1997, 65:766-770

46. Bardocz S, Duguid TJ, Brown DS, Grant G, Pusztai A, White A and Ralph $A$ The importance of dietary polyamines in cell regeneration and growth. Br J Nutr 1995, 73:819-828

47. Forget $P$, Degraeuwe PLJ, Smeets $C$ and Deutz NEP Fasting gastric fluid and fecal polyamine concentrations in premature infants. J Ped Gastroenterol Nutr 1997, 24:389-392

48. Forget P, Sinaasappel M, Bouquet J, Deutz NEP and Smeets C Fecal polyamine concentration in children with and without nutrient malabsorption. J Ped Gastroenterol Nutr 1997, 24:285-288

49. Noack J, Dongowski G, Hartmann L and Blaut $M$ The human gut bacteria Bacteroides thetaiotaomicrom and Fusobacterium varium produce putrescine and spermidine in cecum of pectinfed gnotobiotic rats. I Nutr 2000, I 30: | 225-|23 |

50. Seiler N, Sarhan S, Grauffel C, Jones R, Knödgen B and Moulinoux JP Endogenous and exogenous polyamines in support of tumor growth. Cancer Res 1990, 50:5077-5083 
51. Meyskens FL and Gerner EW Development of difluoromethylornithine (DFMO) as a chemoprevention agent. Clin Cancer Res 1999, 5:945-95।

52. Lieberman R, Nelson WG, Sakr WA, Meyskens FL, Klein EA, Wilding G, Partin AW, Lee JJ and Lippman SM Executive summary of the National Cancer Institute Workshop: Highlights and recommendations. Urology 200I, 57:4-27

53. Einspahr JG, Nelson MA, Saboda K, Warneke J, Bowden GT and AIberts DS Modulation of biologic endpoints by topical difluoromethylornithine (DFMO), in subjects at high-risk for nonmelanoma skin cancer. Clin Cancer Res 2002, 8:149-155

54. Gupta S, Ahmad N, Marengo SR, MacLennan GT, Greenberg NM and Mukhtar $\mathrm{H}$ Chemoprevention of prostate carcinogenesis by alpha-difluoromethylornithine in TRAMP mice. Cancer Res 2000, 60:5I25-5I33

55. Love RR, Jacoby R, Newton MA, Tutsch KD, Simon K, Pomplun M and Verma AK A randomized, placebo-controlled trial of low-dose $\alpha$-difluoromethylornithine in individuals at risk for colorectal cancer. Cancer Epidemiol Biomarkers Prev 1998, 7:989-992

56. Fabian CJ, Kimler BF, Brady DA, Mayo MS, Chang CHJ, Ferraro JA, Zalles CM, Stanton AL, Masood S, Grizzle WE, Boyd NF, Arneson DW and Johnson KA A phase II breast cancer chemoprevention trail of oral alpha-difluoromethylornithine: Breast tissue, imaging, and serum and urine biomarkers. Clin Cancer Res 2002, 8:3105-3।17

57. O'Shaughnessy JA, Demers LM, Jones SE, Arseneau J, Khandelwal P, George T, Gersh R, Mauger D and Manni A alpha-difluoromethylornithine as treatment for metastatic breast cancer patients. Clin Cancer Res 1999, 5:3438-3444

58. Meyskens FL, Gerner EW, Emerson S, Pelot D, Durbin T, Doyle K and Lagerberg W Effect of alpha-difluoromethylornithine on rectal mucosal levels of polyamines in a randomized, doubleblinded trial for colon cancer prevention. J Nat I Cancer Inst 1998 90:1212-1218

59. Hudson EA, Dinh PA, Kokubun T, Simmonds MSJ and Gescher A Characterization of potentially chemopreventive phenols in extracts of brown rice that inhibit the growth of human breast and colon cancer cells. Cancer Epidemiol Biomarkers Prev 2000, 9:1163-1170

60. Plummer SM, Holloway KA, Manson MM, Munks RJL, Kaptein A, Farrow $S$ and Howells $L$ Inhibition of cyclo-oxygenase 2 expression in colon cells by the chemopreventive agent curcumin involves inhibition of NF-kB activation via the NIK/IKK signalling complex. Oncogene 1999, 18:6013-6020

6I. Seiler N, Delcros JG, Vaultier M, Le Roch N, Havouis R, Douaud F and Moulinoux JP Bis(7-amino-4-azaheptyl)dimethylsilane and Bis(7-ethylamino-4-azaheptyl)dimethylsilane: Inhibition of tumor growth in vitro and in vivo. Cancer Res 1996, 56:56245630

62. Bergeron RJ, Hawthorne TR, Vinson JR, Beck DE Jr and Ingeno MJ Role of the methylene backbone in the antiproliferative activity of polyamine analogues on LI 210 cells. Cancer Res 1989, 49:2959-2964

63. Aboul-Enein HY and Al-Duraibi IA Separation of several free polyamines and their acetylated derivatives by ion-pair reversed-phase high performance liquid chromatography. Biomed Chrom 1998, 1 2:291-293

64. Baker MA, Cerniglia GJ and Zaman A Microtiter plate assay for the measurement of glutathione and glutathione disulfide in large numbers of biological samples. Anal Biochem 1990, 190:360-365

65. Snedecor GW and Cochran WG Analysis of Variance. In: Statistical Methods (Edited by: Snedecor GW, Cochran WG) Ames: The lowa State University Press 1980, 21 5-237

66. Afifi $A A$ and Azen SP The Analysis of Variance. In: Statistical Analysis A Computer Oriented Approach (Edited by: Afifi AA, Azen SP) London: Academic Press, Inc 1979, 198-273

67. Howells LM, Gallacher-Horley B, Houghton CE, Manson MM and Hudson EA Indole-3-carbinol Inhibits Protein Kinase B/Akt and Induces Apoptosis in the Human Breast Tumor Cell Line MDA MB468 but not in the Nontumorigenic HBLI00 Line. Mol Cancer Ther 2002, I: I 161-1 I 72

68. Ge X, Fares FA and Yannai S Induction of apoptosis in MCF-7 cells by indole-3-carbinol is independent of p53 and Bax. Anticancer Res 1999, 19:3199-3204
69. Meng $\mathrm{QH}$, Goldberg ID, Rosen EM and Fan SJ Inhibitory effects of indole-3-carbinol on invasion and migration in human breast cancer cells. Breast Cancer Res Treat 2000, 63:147-152

70. Rahman KMW, Aranha O, Glazyrin A, Chinni SR and Sarkar FH Translocation of Bax to mitochondria induces apoptotic cell death in Indole-3-carbinol (I3C) treated breast cancer cells. Oncogene 2000, 19:5764-577|

71. Bonnesen C, Eggleston IM and Hayes JD Dietary indoles and isothiocyanates that are generated from cruciferous vegetables can both stimulate apoptosis and confer protection against DNA damage in human colon cancer cell lines. Cancer Res 2001, 61:6120-6130

72. Gamet L, Cazenave Y, Trocheris V, Denis-Pouxviel C and Murat J-C Involvement of ornithine decarboxylase in the control of proliferation of the HT29 human colon cancer cell line. Effect of vasoactive intestinal peptide on enzyme activity. Int J Cancer 1991, 47:633-638

73. Ray RM, Zimmerman BJ, McCormack SA, Patel TB and Johnson LR Polyamine depletion arrests cell cycle and induces inhibitors p2 I(Wafl/Cip I), p27(Kip I), and p53 in IEC-6 cells. Am J Physiol 1999, 276:C684-C691

74. Nemoto T, Kamei $S$, Seyama $Y$ and Kubota $S$ p53 independent $\mathbf{G}(\mathrm{I})$ arrest induced by DL-alpha-difluoromethylornithine. $\mathrm{Bi}$ ochem Biophys Res Comm 200I, 280:848-854

75. Ray RM, McCormack SA and Johnson LR Polyamine depletion arrests growth of IEC-6 and CaCo-2 cells by different mechanisms. Am J Physiol 200I, 28 I:G37-G43

76. Seiler N, Duranton B, Gosse F and Raul F Spermine cytotoxicity to human colon carcinoma-derived cells $(\mathrm{CaCo}-2)$. Cell Biol Tox 2000, 16:117-130

77. Tipnis UR and He G-Y Mechanism of polyamine toxicity in cultured cardiac myocytes. Toxicol in Vitro 1998, 1 2:233-240

78. He Y, Kashiwagi K, Fukuchi J-I, Terao K, Shirahata A and Igarashi K Correlation between the inhibition of cell growth by accumulated polyamines and the decrease of magnesium and ATP. Eur J Biochem 1993, 21 7:89-96

79. Brunton VG, Grant MH and Wallace HM Spermine toxicity in BHK-2I/CI 3 cells in the presence of bovine serum: the effect of aminoguanidine. Toxicol in Vitro 1994, 8:337-34I

80. Brunton VG, Grant MH and Wallace HM Spermine toxicity and glutathione depletion in BHK-2 I/CI 3 cells. Biochem Pharmacol 1990, 40:1893-1900

8I. Brunton VG, Grant MH and Wallace HM Mechanisms of spermine toxicity in baby-hamster kidney (BHK) cells. Biochem J 199I, 280:193-198

\section{Pre-publication history}

The pre-publication history for this paper can be accessed here:

http://www.biomedcentral.com/1471-2407/3/2/prepub

Publish with Bio Med Central and every scientist can read your work free of charge

"BioMed Central will be the most significant development for disseminating the results of biomedical research in our lifetime. "

Sir Paul Nurse, Cancer Research UK

Your research papers will be:

- available free of charge to the entire biomedical community

- peer reviewed and published immediately upon acceptance

- cited in PubMed and archived on PubMed Central

- yours - you keep the copyright 